\title{
vianinha e sua luta política no campo estético sob a ditadura
}

Vianinha and his political struggle in the aesthetical field under the dictatorship Fernando Bustamante ${ }^{1}$ e Daniel Angyalossy Alfonso ${ }^{2}$

Resumo: $O$ artigo propõe uma breve análise de aspectos temáticos, formais e políticos da obra dramatúrgica de Oduvaldo Vianna Filho (Vianinha) em suas diferentes fases, com ênfase para seu retrato da classe média e os dilemas políticos enfrentados por esta. Também procura articular essa visão com a noção de um teatro "nacional e popular" que orienta a produção do autor em sua totalidade. A análise busca retomar alguns pesquisadores da obra de Vianna e articular como as concepções políticas do autor, enquanto militante do Partido Comunista Brasileiro (PCB), dialogam com as suas opções dramatúrgicas e de debates, tanto sobre a produção teatral do período, como sobre as estratégias políticas da esquerda organizada, tendo em vista as mudanças bruscas na situação política e os impactos diretos desta tanto sobre as condições de produção como sobre as opções políticas e de temática nas peças.

Palavras-Chave: Oduvaldo Vianna Filho; teatro na ditadura; $\mathrm{PCB}$; teatro brasileiro; teatro e política; teatro nacional-popular.

1 Doutorando em Estudos Linguísticos e Literários em Língua Inglesa na USP.

E-mail:bustamantefer@gmail.com.

2 Graduado em História - USP. E-mail: dan.al1738@gmail.com.

*Artigo recebido em 23/06/2019 e aprovado para publicação em 27/11/2019. 
Abstract: The article briefly analyses formal, thematical and political aspects in Oduvaldo Vianna Filho's (Vianninha) dramaturgical work along its different stages, with emphasis in its middle class representation and its political dilemmas. It also seeks to articulate this portrait with the notion of an "national and popular" theatre which has guided the whole production of this author. This analysis brings about some researchers of Vianna's work as well as articulate the specific manner in which the political conceptions of the author - being an active member of the Brazilian Communist Party (PCB) - relates to his dramaturgical options and with the debates regarding the theatrical production of the period and the political strategic debates in the left organizations is his time, considering the abrupt changes in the political situation and the direct impacts of this in the material conditions of work and the political and thematic aspects in his plays.

Keywords: Oduvaldo Vianna Filho; theatre during the military regime; PCB; brazilian theatre; theatre and politics; national and popular theatre.

Sob o regime militar, a produção cultural e artística representou um dos polos mais empenhados de resistência no imediato pós-golpe. No teatro, em particular, os distintos caminhos foram buscados por muitos artistas em meio a um cenário cada vez mais difícil, em que a censura se aguçava e, pós $\mathrm{Al}$-5, em dezembro de 1968, já era quase incontornável. $\mathrm{E}$, para além da censura, as questões que permeavam os debates e dilemas dos artistas de esquerda remetiam aos problemas trazidos pelo próprio golpe em relação a questões de estratégia política, da possibilidade da relação dos artistas com a classe trabalhadora, e a viabilidade de seguir produzindo uma obra crítica em um momento no qual vigorava não apenas a censura ideológica, mas se implementava no Brasil a indústria cultural, com a consolidação da Globo como o grande monopólio de comunicação que, sob a benção do regime, ganhava proporções inéditas para uma empresa desse ramo no país.

Oduvaldo Vianna Filho, militante político, ator e dramaturgo, em sua carreira incrivelmente fértil, apesar da brevidade imposta por uma morte prematura, com apenas 38 anos, expressa grande parte dessas questões fundamentais do período. A busca de Vianna, como sintetizado por uma das grandes estudiosas de sua obra, Maria Silvia Betti, era por um teatro "nacional e 
popular"2, e sua obra se constrói como a de um "autor em progresso" (BETTI, 1997, p. 311), por meio da constante releitura crítica de sua própria trajetória e uma apurada leitura dos caminhos do teatro brasileiro, tanto no período que lhe antecedeu, como no momento em que ele próprio atuava.

\section{antes do golpe: da representação do país nos palcos à busca pela a ção política}

Vianna chega ao teatro pela via da militância política. E tanto o comunismo como a arte já estavam presentes em sua trajetória desde a infância, já que seus pais eram engajados em ambos. Em 1955, ao lado de Vera Gertel e Gianfrancesco Guarnieri, entre outros, funda o Teatro Paulista do Estudante (TPE), uma iniciativa atrelada à União Paulista dos Estudantes Secundários e ao Partido Comunista Brasileiro (PCB). O grupo faz um acordo para ensaiar na sede do Teatro de Arena em troca de fazer figurações em suas peças e, em pouco tempo, eles se incorporam ao Arena. Sua entrada, somada à de Augusto Boal, recém-chegado dos EUA, representa um momento de mudança de rumos para o grupo.

O ponto de viragem do Arena foi a montagem de "Eles não usam black-tie", peça de Guarnieri, em 1958. Vianna faz sua estreia como dramaturgo na esteira do sucesso atingido pelo Arena nessa montagem, com "Chapetuba futebol clube". A busca pela representação do nacional no teatro ganha ali os primeiros passos para Vianna, e ele afirma que o teatro brasileiro passa por uma "Fase da conscientização diante de realidade que não pode mais ser ignorada" (VIANNA FILHO, 1958, p.23). No calor do momento, ainda em 1958, o autor vislumbra que ali se desenha um marco, um divisor de águas em relação ao passado teatral do país, e que é sua geração que encabeça esse processo: "A resposta vem dos jovens na sua maioria, e são os jovens que compõem a maioria do teatro brasileiro: um teatro nacional. Um

2 Os conceitos de "nacional e popular" que Vianinha tinha como horizonte político eram tributários das concepções oriundas do stalinismo que orientavam o Partido Comunista Brasileiro (PCB). Como aponta Ricardo Costa, dirigente do PCB, a "(...) luta por uma cultura nacional-popular casava-se com a estratégia da revolução democrático-burguesa." in: https://www.marxists.org/ portugues/tematica/ano/mes/cultural.htm\#trı. Portanto, Vianna se orientava dentro dos marcos políticos traçados por seu partido, em que a aliança com setores nacionalistas da burguesia consistia numa etapa necessária para um suposto fortalecimento do proletariado na perspectiva de uma futura revolução socialista. 
teatro que procure a realidade brasileira, que apreenda o sentido do seu desenvolvimento e que lute ao lado dele" (VIANNA FILHO, 1958, p. 24)

Vale destaca que o público quelotava oArena era compostofundamentalmente pelos estudantes da Faculdade de Filosofia, Ciências e Letras (FFCL) da USP, cuja sede na Rua Maria Antônia era muito próxima ao Arena. A impossibilidade de atingir, a partir do pequeno teatro de Arena no centro de São Paulo, um público proletário, distante do teatro, seria o limite fundamental que enxergaria a partir dos anos 1960, e que o motivaria a procurar novos rumos para seu teatro. Assim ele refletiu, em 1962, sobre as limitações da atuação do Arena:

O Teatro de Arena (...) trazia dentro de sua estrutura um estrangulamento que aparecia na medida mesmo em que cumprisse a sua tarefa. O Arena era porta-voz das massas populares num teatro de cento e cinquenta lugares.... O Arena não atingia o público popular e, o que é talvez mais importante, não podia mobilizar um grande número de ativistas para o seu trabalho. (VIANNA FILHO, 1962, p. 93).

Assim, durante a temporada do Arena no Rio, deu o pontapé inicial para o que viria a ser o Centro Popular de Cultura da União Nacional dos Estudantes (UNE), junto a Chico de Assis. Na matéria tratada, Vianna quis penetrar nas camadas mais profundas da exploração capitalista, desvendando frente ao público suas engrenagens. Para isso, foi procurar a parceria do Instituto Superior de Estudos Brasileiros (ISEB), e, com o apoio teórico de Carlos Estevam Martins, escreveu "A mais-valia vai acabar, seu Edgar". Quanto à forma, Vianna rompe definitivamente com o drama realista/naturalista, e faz uma peça com cenas onde procura desvendar cenicamente um conceito que é pilar da economia marxista, a mais-valia. Assim, com cenas como a da feira, onde o "Desgraçado 4" (ou D4) leva o "Desgraçado 1" (D1) para trocar seu tempo de trabalho por mercadorias, Vianna radicaliza o caminho que havia começado a tomar no Arena, vendo que, para chegar à explicação do mundo capitalista, era preciso assumir uma forma nova - os mesmos passos dados pelos criadores do teatro épico na Europa e Rússia. Rompe a quarta parede, as unidades de espaço e tempo, entre outros recursos utilizados que extrapolam a forma dramática, para chegar à explicação cênica da mais-valia: 
DESGRAÇADO 4 - Ouve aí - é uma feira. Vende de tudo lá... Só que ao invés de dinheiro, vende tudo pelo tempo de trabalho que levou pra fazer... Vem comigo mas só pode comprar o que você compra todo dia, mais nada. Você vem?

$[\ldots]$

OITAVO VENDEDOR - Olha o apartamento, presidento! Vista para o mar... aperta um botão - vista para o quarto da vizinha. Cinco quartos, oito salões... salão pra cuspir, salão pra pensar onde ir, salão pra pensar o que vai fazer com tanto salão... DESGRAÇADO 1 - Quanto é?

OITAVO VENDEDOR - Trinta horas de trabalho por dia.

DESGRAÇADO 1 (chora) - Não quero mais, Quatro. Tem tudo aqui... e eu não posso ter nada! Já comprei tudo o que eu uso todo dia...

DESGRAÇADO 4-Quanto você gastou?

DESGRAÇADO 1 - Duas horas... Deixa eu comprar mais coisa, seu Coisa.

DESGRAÇADO 4 - Não. Só compra no sonho o que você compra acordado. É a décima vez que o autor me faz dizer isso... Depois a gente encontra ele.

DESGRAÇADO 1 (ao público) - Eu vou guardar essas seis horas de trabalho que sobraram... Depois sonho sozinho e compro mais coisa, seu Coisa.

PORTEIRO (aparecendo ao fundo) - Essas horas ficam conosco, cavalheiro...

DESGRAÇADO 1 - Mas...

[...]

DESGRAÇADO 4 - Entendeu?

DESGRAÇADO 1-Que sonho mais besta, ô! Eu trabalhei oito horas... seu grudento! DESGRAÇADO - E gasta pra viver - pra poder trabalhar no dia seguinte só duas horas... As outras seis horas... ficam na feira... é o lucro! (VIANNA FILHO, 1960, p. $68 ; 71-72)$

O CPC da UNE, em sua breve vida, se vinculou profundamente - embora não "oficialmente" - ao projeto "nacional e popular" ao qual estava também ligado o PCB, partido do qual Vianna fazia parte: eram tributários, ambos, da estratégia reformista propugnada pelo governo de João Goulart, cujo centro da atuação eram as "reformas de base"3. Nesse momento, Vianna colocou

3 O apoio do PCB ao governo de João Goulart se fundamenta na concepção de origem stalinista que divide, nos países de desenvolvimento capitalista atrasado como o Brasil, a revolução em distintas etapas, o que colocaria como tarefa imediata a consolidação de alianças com setores da burguesia que caracterizavam como potencialmente revolucionários. De acordo com a resolução política do V Congresso do PCB, de 1960: "As tarefas fundamentais que se colocam hoje diante do 
em prática seu desejo de sair do pequeno espaço do Teatro de Arena e ir para as ruas, encabeçando o que seria o maior projeto de teatro épico e a mais ampla experiência de agitação e propaganda (Agitprop) já realizada no Brasil. Peças escritas por Vianna, sozinho ou em parceria com seus colegas de CPC, tinham um caráter marcadamente de agitação e propaganda política, bebendo diretamente das fontes do teatro épico que nascera no calor das revoluções russa e alemã ${ }^{4}$. A ambição de Vianninha era essa:

E um movimento de massas só pode ser feito com eficácia se tem como perspectiva inicial a sua massificação, sua industrialização. É preciso produzir conscientização em massa, em escala industrial.Só assimé possível fazer frente ao poder econômico que produz alienação em massa" (VIANNA FILHO, 1962, p. 93).

Sua ideia era a de que o Arena havia produzido um "teatro inconformado", e era necessário produzir um "teatro de ação" (1962, p. 93).

Em "Brasil, versão brasileira" utiliza o expediente da projeção de slides, que cumprem um papel de comentadores da cena, um elemento épico-narrativo central para a peça que remete diretamente aos expedientes elaborados por Erwin Piscator nos anos de 1920, com a introdução da projeção de filmes com o mesmo papel narrativo. A peça, embora centrada na concepção de uma agitação e propaganda cujo objetivo não era o de aprofundar as contradições,

povo brasileiro são a conquista da emancipação do país do domínio imperialista e a eliminação da estrutura agrária atrasada, assim como o estabelecimento de amplas liberdades democráticas e a melhoria das condições de vida das massas populares. Os comunistas se empenham na realização dessas transformações, ao lado de todas as forças patrióticas e progressistas, certos de que elas constituem uma etapa prévia e necessária no caminho para o socialismo. (...) A burguesia brasileira, na sua grande maioria, em virtude de seus próprios interesses de classe, é levada a chocar-se com o capital monopolista estrangeiro, que representa obstáculo à expansão dos seus negócios. A burguesia ligada aos interesses nacionais possui um duplo carácter. Pertencendo a um país explorado pelo imperialismo, encerra um potencial revolucionário e é uma força capaz de opor-se à dominação imperialista. In: https://www.marxists.org/portugues/tematica/1960/og/congresso.htm

4 De acordo com depoimento de Fernando Peixoto, era a experiência de Erwin Piscator na Alemanha a principal fonte de inspiração nesse momento: "o CPC nasceu muito sobre o signo de Piscator. a gente andava com o livro 'Teatro Político' de Piscator debaixo do braço o tempo todo. Afinal, ele propunha um teatro de agitação, deliberadamente proletário, que procurava levantar as massas. (...) Não estou querendo reduzir o CPC a Piscator, mas sim querendo dizer que essa noção meio sectarizada, meio dogmática que o Piscator tinha, penetrou muito no CPC. Piscator foi a primeira Bíblia de teatro político que caiu nas nossas mãos" (BARCELLOS, 1994, p. 203). 
mas sim exortar o público à ação política, não apresenta uma versão simplificadora dos conflitos de classe, explora as contradições inclusive da política do PCB, colocando em xeque a partir do desenvolvimento da peça a política de aliança de classes com a burguesia industrial, vista então pela política de frente popular do PCB como supostamente "progressista". Vidigal, personagem que retrata a burguesia nacionalista, diz no início da peça "[...] Em minha fábrica não há um centavo estrangeiro. Nem um centavo. Oitenta por cento do que produzo é comprado pela Petrobrás" (PEIXOTO, 1989, p. 258), e afirma que votará no Conselho Nacional do Petróleo pela suspensão do contrato com a Kellog, empresa americana responsável pela construção da refinaria em Duque de Caxias. Mas esse mesmo empresário "nacionalista" recusa aumento aos operários, demite-os, combate os comunistas e o sindicato, e suplica ao Citibank por um empréstimo, mostrando na peça algo muito diferente de uma idílica burguesia progressista e independente.

Para atuar diretamente em defesa da reforma universitária de Jango, o CPC colocou de pé a peça escrita a muitas mãos - entre elas a de Vianna - "Auto dos 99\%", uma crítica fulminante à universidade brasileira que apresentava ao público um panorama abrangente, da colonização do país ao momento presente.

Em relação aos conflitos pela terra, tema candente da luta de classes no Brasil e em particular no período pré-golpe, Vianninha escreveu "Quatro quadras de terra", que fazia parte das apresentações itinerantes do CPC junto à UNE Volante, e "Os Azeredos mais os Benevides", montagem que era preparada no momento em que os militares acabaram com o CPC colocando a UNE na ilegalidade.

A experiência do CPC, como se sabe, foi interrompida bruscamente pelo golpe civil-militar de 1964. Não à toa, um dos primeiros alvos do novo regime foi a sede da UNE, incendiada criminosamente em 31 de março.

\section{a classe média vai ao palco: uma ode à resistência que não houve}

O golpe civil-militar, arquitetado pela classe dominante brasileira em parceria direta com o imperialismo estadounidense, consistiu numa contrarrevolução preventiva em um momento de um dos maiores ascensos da luta de 
classes no país. O PCB cumpriu um papel determinante ao não organizar a resistência, sendo que um setor expressivo da base das forças armadas, junto a trabalhadores organizados, aguardavam instruções para combater. No campo, as Ligas Camponesas vinham protagonizando importantes embates com o latifúndio, chegando a erguer experiências de comunas rurais como a de Trombas e Formoso 5 .

Como aponta Iná Camargo, a palavra de ordem do PCB de "recuo organizado", que na prática se traduzia por uma ausência de resistência ao golpe e pela perseguição e massacre das principais lideranças ou seu exílio, teve sua expressão no teatro 6 . Vianna, ao lado de Armando Costa e Paulo Pontes, do Arena e de outros ex-integrantes do CPC, fez o Show Opinião, com direção de Augusto Boal, como a primeira expressão de protesto ao golpe advinda do mundo artístico. Contudo, contraditoriamente, "(...) salvo por uma ou outra referência incidental, (...) nada mais permite supor que a peça tenha sido escrita depois da maior hecatombe política da história do país" (COSTA, 1996, p.101). É um momento fundamental no plano artístico, de mudança de perspectivas, e politicamente também atesta a grande desorientação que a esquerda, sob a égide do PCB, atravessava no momento. Não se expressa em "Opinião" a percepção da dimensão da derrota histórica capitaneada pela política conciliatória do "partidão", e nisso Iná Camargo aponta a semelhança entre esse espetáculo e o "Arena conta Zumbi", de 1965: "(...) esses espetáculos lidam com o golpe militar como se ele não passasse de um acidente de percurso, a ser removido sem maiores dificuldades, nisto acompanhando conhecidas 'análises de conjuntura' elaboradas no calor da hora" (COSTA, 1996, p.102).

A classe média, já então, passa a ser uma protagonista da obra de Vianna, expressando um primeiro momento de fratura entre os artistas e aquele que figurara como o "povo" no momento precedente de sua obra: a classe 5 Em 1953, camponeses implantaram uma espécie de república paralela: "Tromba-Formoso abrangeu uma área de 10 mil quilômetros quadrados ao norte de Goiás, há 250 quilômetros de Brasília, onde se estabeleceu um governo paralelo, baseado em comitês políticos e milícias armadas e promoveu, em toda a região ocupada, uma reforma agrária. (SALLES; MATOS, 2007).

6 '"Opinião' corresponde à palavra de ordem de 'recuo organizado' dada pela direção do PCB aos seus militantes no 'front cultural' e não apenas escamoteia essa situação como ainda a apresenta como um 'avanço' decorrente de 'crítica' aos erros do período anterior. Mais grave: os 'erros' do período anterior nada mais são do que os poucos momentos em que militantes do partido estiveram em sintonia com os avanços reais nas lutas populares (no campo, na cidade e no 'front cultural'), agora entendidos negativamente como 'radicalização'"'. (COSTA, 1996, p. 110). 
trabalhadora. Nara Leão é quem representa essa "classe média" em Opinião, conformando no palco a tríada com Zé Keti - representando a "classe popular" dos morros - e João do Vale - expressando a "classe popular" do campo, na figura do retirante. É um dado expressivo também a nova mudança de público que as condições políticas impuseram; frente ao impasse sobre onde encenar o Opinião, a sugestão do próprio Vianninha foi o retorno ao mesmo lugar onde ele havia colocado fim à sua participação no Arena: um palco montado no shopping center da Rua Siqueira Campos, em Copacabana. O proprietário do shopping era ninguém menos que o Senador Arnon de Mello, oligarca e pai do futuro presidente Fernando Collor (GULLAR, 2011). Assim, o público voltava a ser também a classe média, como eram os frequentadores do Arena cujo escopo Vianna decidira extrapolar ao fundar o CPC.

\section{a classe média encurralada}

O golpe havia cortado os laços ainda incipientes que, por meio do CPC, principalmente, os artistas começavam a criar com setores explorados e oprimidos, e aqueles que se colocavam em aliança com seu projeto "nacional e popular", como expressava a aliança do CPC com a UNE e o movimento estudantil, com as Ligas Camponesas e, de forma muito mais tênue, com os setores organizados da classe operária. Do ponto de vista político, predominava, ainda que nem sempre de forma totalmente consciente, a visão hegemônica do $P C B$, de que o governo nacionalista burguês de João Goulart expressava os interesses do "povo", e que o adversário fundamental era o imperialismo - visão na qual as distinções fundamentais de classe encontravam-se dissolvidas, em segundo ou terceiro plano frente à estratégia de aliança entre setores vistos como "progressistas".

Tal como o PCB, Vianna não faz um balanço político da estratégia conciliatória e de seu fracasso frente ao golpe militar. Outros setores, como Augusto Boal expressa em sua célebre polêmica com a concepção de Brecht - que foi defendida no debate brasileiro por Anatol Rosenfeld - de que o povo brasileiro precisa, sim, de heróis (ROSENFELD, 1982). Essa concepção, que se expressa principalmente na peça "Arena conta Tiradentes", está refletida em suas posições políticas, que convergem com o apoio à estratégia da guerrilha e sua filiação à Aliança Libertadora Nacional (ALN), organização 
oriunda de uma ruptura com o PCB e cujo balanço a leva à guerrilha dirigida por Carlos Marighella.

Vianninha, num sentido oposto, permanece fiel às concepções do "partidão". Mas suas possibilidades de trabalho, com a desarticulação do CPC e a ruptura dos laços com os movimentos estudantil, de camponeses e de trabalhadores - nesse momento profundamente debilitados pelo golpe - levam-no a um impasse e à necessária mudança de rumos, que se expressam também nos debates teóricos sobre os impasses do teatro como veremos adiante.

Otema da classe média e sua impotência naquele momento surgem com força, e os "pequenos dilemas" desse setor passam a figurar em primeiro plano, denotando que a concepção de "popular" de Vianna tem seu eixo deslocado pela situação política advinda da ditadura. "Mão na Luva", apresentando os dilemas de um casal, aponta nesse sentido. Mas o sentido dessa mudança de foco não é o de uma mudança abrupta de sua perspectiva política, mas sim o da representação de um impasse histórico sob determinado ponto de vista. Podemos perceber essa questão mesmo em "Mão na Luva", em que o impasse político dessa camada social entra de viés, por exemplo, no diálogo sobre a censura - motivada não apenas politicamente, mas por fatores econômicos - que vai se instalando na redação da revista onde o marido trabalha:

ELA - Portela pediu mesmo demissão da revista?

$E L E-E ́$.

ELA - Bandeira Pessoa aceitou?

ELE - Aceitou. (Longa pausa)

ELA - Foi por que cortaram aquelas duas reportagens dele?

ELE - É. (Pausa)

ELA - Bandeira vai continuar cortando reportagem?

ELE - Importou aquelas máquinas novas, muito dinheiro, que não tem pra poder pagar, a revista não publica de agora em diante determinadas coisas... (VIANNA FILHO, 1966, p.23)

Nesse sentido, é muito ilustrativo o comentário tecido pelo autor a respeito da montagem de sua peça, "A longa noite de Cristal", em 1970, que se choca frontalmente com suas intenções em relação ao texto. A peça trata justamente de um dilema moral e político do apresentador Cristal, que 
noticia um evento testemunhado por ele: uma mulher prestes a dar à luz tem seu atendimento recusado por um hospital, e chega a parir seu filho numa praça. A notícia, contudo, refere-se a um hospital que é patrocinador da emissora e o apresentador é intimado a desmentí-la. Recusando-se, ele perde o emprego. Ao criticar a montagem de Celso Nunes, o autor diz:

a peça é sobre um pequeno drama de um indivíduo e sobre a urgente necessidade de não soçobrarmos em pequenos dramas; fizeram-na um drama diluviano, quase alegórico, que vale a pena ser vivido, porque todo grande drama vale a pena ser vivido; o personagem "Cristal" é um personagem que se desatarraxou da vida e ainda assim é tratado por todos na ponta dos dedos; a encenação faz de Cristal um tresloucado homem superior que é tratado a pontapés por todos. A peça tenta amarrar os comportamentos às situações objetivas, grudá-los com cola-tudo às situações objetivas; o espetáculo é voluntarista - as pessoas agem de tal ou qual modo porque querem. Essas três inversões de concepção e não de estilo (que terminam resultando numa inversão de estilo) tornaram-me irreconhecível a peça. Contrária à minha concepção. Exatamente contrária. (VIANNA FILHO, 1970a, p. 131).

Dentre as diversas cenas que poderiam explicitar a possibilidade dos contrastes apontados entre a concepção de Vianna e de Nunes, tomamos a de sua conversa com o filho, que, visivelmente, trata o pai de forma condescendente quando este o procura para tentar obter algum respaldo à atitude que o levara a ser demitido da televisão:

Cristal - [...] sabe o que eu fiz hoje?... mandaram eu desmentir uma notícia... não desmenti... ali na bucha, aguentei.

Celso - Você deu uma dessa, cara? Boa, pai, boa.

Cristal - ... estou certo?

Celso - ... está certo demais, cara, demais!

Cristal - Isso, filho, isso... você não fica me admirando?

Celso - Paca, claro

Cristal - ... mesmo que não adiante pra nada, não é? Mesmo que prejudique o Murilo? Mesmo que eu nunca tenha ajudado o Murilo e o filho da mãe ficou do 
meu lado? E não sei o que vai ser da segunda edição, hein? Mesmo tendo sido só por teimosia...?

Celso - Que é isso, pai. Não fica assim. (VIANNA FILHO, 1969, p. 81-82)

Em "Corpo a Corpo", de 1971, Vianna recorre a um monólogo, uma forma dramatúrgica que coloca a nu, em primeiro plano, o "pequeno drama" da personagem Vivacqua. Afundado em uma vida que repugna, às portas de um casamento sem paixão e com uma carreira de publicitário na qual não vê sentido, acompanhamos o protagonista numa madrugada de seu dilema, buscando desesperadamente algum sentido para combater o seu "desatarraxo" da vida. Mas, diferente de Cristal, Vivacqua não é o retrato de um voluntarista que faz de seu "pequeno drama" uma ilusão de uma grande batalha moral. Como é característico das peças de Vianna, os conflitos morais de suas personagens são "amarrados à situação objetiva" da questão econômica. A classe trabalhadora aparece vista de longe, sob a lente de Vivacqua - um representante amargurado dos produtores de ilusões de uma sociedade de consumo e perpetuador do fetichismo da mercadoria - cujas possibilidades de irmanamento e reconhecimento com o trabalhador se encontram rompidas pela materialidade de sua vida e por seu papel social. Nesse sentido, a escolha por um monólogo é também expressiva de tal isolamento:

VIVACOUA - [...] propaganda é isso, uma corrida desesperada de todo mundo prá vender cenários e humilhação... sou pago prá não tomar conhecimento do povo, jogar luxo nos olhos dele... sou pago prá provar prá ele que uma geladeira é um ser superior que uma loja é um templo onde se dá a multiplicação dos liquidificadores... quem não tem uma batedeira de bolo não entra no Reino dos Céus... a gente fica tão metido dentro daquela Agência, tão atrás tricas e futricas que a gente esquece que foram eles que fizeram a geladeira, pomba, com o maçarico na mão... a gente começa a acreditar que somos nós que carregamos o povo nas costas... somos nós que temos que trabalhar feito cruzados prá convencer essa gente a acreditar no conforto, nos liquidificadores... eles ficam de outro país, entende? outro sangue, metabolismo diferente, é outra raça... (VIANNA FILHO, 1970b, p. 10-11)

As crises morais e existenciais de Vivacqua sucumbem diante da sedutora oferta de um trabalho com uma empresa estrangeira, mostrando que, ao fim 
e a cabo, a sua moral sempre esteve à venda e submetida à imperiosidade do poder econômico da burguesia.

Aqui, o protagonista é um perturbado indivíduo da classe média, mas o modelo de dilema e seus pressupostos remontam às origens de Vianninha em "Chapetuba Futebol Clube", com os jogadores Durval e Maranhão deixando de lado os interesses de seu pequeno time em nome das oportunidades econômicas que lhes são ofertadas. Da mesma forma, em "Moço em estado de sítio" vemos uma estrutura similar. É fato que Vianninha teorizava sobre esse conflito das personagens como elemento motor do teatro desde a época do CPC, em 1962:

O teatro é a exposição de um personagem que enfrente um obstáculo qualquer, um obstáculo que fere os limites em que o personagem faz coexistir seus critérios de comportamentos morais, políticos, religiosos, com suas necessidades etc. Uma peça será tanto mais teatral quanto mais impossível for a manutenção desse limite, quanto mais insustentável for a adaptação. $O$ teatro é o momento em que esse limite transparece para o público na sua tensão mais violenta. (VIANNA FILHO, 1962, p. 94).

De forma bastante próxima a suas observações sobre a montagem de Celso Nunes, ele critica o teatro brasileiro precedente por colocar os impasses sempre do ponto de vista subjetivo, sem lidar com as necessidades objetivas: "O nosso teatro social brasileiro investiga esse limite sempre subjetivamente. São sempre os critérios morais e as necessidades morais que se chocam. É sempre o que o personagem acha que deve ser feito, e o que deve ser feito que é fixado." (VIANNA FILHO, 1962, p. 95).

A mudança drástica de seu posicionamento, contudo, está em que em 1962 Vianna defende a saída positiva do dilema, como forma de exortar seu público à ação:

O natural, o necessário, o irrefutável, o certo, em choque dentro de um mesmo personagem. As opções serão sempre as do sacrifício de alguma coisa absolutamente necessária. Para isso é necessário a fábula. Diminuir os desenhos 
subjetivos dos personagens e inundar o palco de acontecimentos exemplares. (VIANNA FILHO, 1962, p. 95).

Para o autor, imbuído do espírito de um teatro de ação que mova o público, era preciso então "Um teatro de criação e não de imitação do real. Um teatro otimista, direto, violento, sátiro e revoltado como precisa ser o povo brasileiro" (1962, p. 95). Essa visão é bastante distinta, no entanto, daquela saída que vemos desenhada para os dilemas dos protagonistas desse segundo momento. Vivacqua cede à sedução de trabalhar junto com uma empresa estrangeira, ganhando fama e fortuna e abrindo mão de todas as promessas que fizera em sua madrugada de dilemas, passando por cima de seus limites morais, por exemplo. Cristal, em meio a seu "pequeno drama", sucumbe, enquanto Vianninha traça ao longo da peça um retrato da indústria midiática que se erguia, e à qual conhecia já muito bem, trabalhando em suas entranhas e fazendo todo o esforço para não sucumbir aos "pequenos dramas" como ocorria com seu personagem.

Em "Nossa vida em família", Vianinha adentra o núcleo familiar de Souza, um ex-funcionário público que, arriscando abrir seu próprio negócio, uma oficina de conserto de rádio, põe a perder sua magra poupança; agora, idoso, Souza e sua esposa, Lu, estão na iminência de não ter onde morar por falta de recursos para pagar o aluguel, e a situação gera um conflito entre os filhos para saber onde alocar o casal. A filha que ascendeu economicamente por meio do casamento, Neli, encarna o dilema da "classe média" frente ao conflito moral; seja por sua incapacidade de impor sua vontade ao marido, seja por usá-lo como pretexto, ela não coloca sua situação econômica mais favorável a serviço de ajudar os pais. Mais uma vez, Vianninha mostra o impasse nas decisões e situações de vida de uma "classe média" esmagada por um contexto econômico que a impõe becos sem saída. Mas não se impõe um acontecimento exemplar, e sim a ilustração da impotência individual. A família, tão comumente idealizada no imaginário burguês, é retratada atravessada por disputas materiais mundanas em torno da situação de penúria material dos pais, Souza e Lu:

Souza - ...qualquer lugar que vocês arranjem pra gente serve... uma casinha pequena e... não faz mal que seja distante... nós não saímos: televisão, um passeio 
por ali mesmo, bate-papo... vidinha curta... se cada um de vocês pudesse entrar com uma pequena...

Roberto - Uma pequena parte das minhas dívidas?

Jorge - Não, Beto, agora não é hora de graça, realmente agora...

Roberto - ...olha como estou sério: aonde vou arranjar dinheiro?

Jorge - ...você podeia dar um tiro nos miolos e deixar o dinheiro do seguro por exemplo...

Roberto - ...e como é que pago a apólice?...

Jorge - ...por exemplo, economizando no choppe, em whisky ou... Cora - ...em vez de reclamar Roberto, era muito bom você me explicar como é que a coisa chegou a esse ponto! Estou em São Paulo há quatro anos e não tinha a menor idéia...

Roberto - Bom filho não depende de geografia, já dizia Tucídides...

Neli - Eu também não sabia, Cora, eu...

Cora - Não é de você, Neli, você é mulher também...

Roberto - ...mas com o marido bem situadinho, situadão...

Cora - ...meu marido? Pelo amor de Deus, é funcionário público, feito papai, com medo de largar, vai ficando, vai...

Neli - ...meu marido é rico, Roberto, mas é dinheiro dele, eu não tenho nada, sou pobre, eu...

Roberto - ...mas não há coisa mais pobre no mundo que você, querida, imagino que essa roupa, por exemplo, você conseguiu na LEA, não foi? Ou foi na Casa do Pequeno Jornaleiro?

Neli - ...assim, não, Roberto, por favor, assim eu, assim vou embora...

Cora - Calma, gente, calma! Tenho a impressão que nós estamos perdendo um pouco a chamada compostura!

Jorge - Foi você quem começou, Cora.

Cora - Quem começou foi você com o Roberto, ora! (Silêncio)

Souza - ...é meio engraçado... dois de nós pudemos tomar conta de cinco de vocês... cinco de vocês não podem tomar conta de nós dois? (VIANNA FILHO, 1971)

Se considerarmos que a escrita e publicação dessa peça se situa justamente no período da ditadura propagado como o "milagre econômico", em que não eram poucos os esforços oficialistas do governo em propagar a ideia de um "Brasil potência", alardeando o crescimento do PIB, vemos como há limitada às estreitas possibilidades da época - uma mordaz crítica do autor ao mostrar uma situação de pauperismo popular no país em que nem mesmo 
uma família de classe média, com um pai advindo do funcionalismo público, era capaz de garantir uma aposentadoria com o mínimo de conforto e segurança. O drama como forma é movido por questões materiais candentes.

O sentido da busca de Vianninha está na contramão de outras tendências do teatro de esquerda, fundamentalmente do Oficina, de José Celso Martinez Corrêa, que busca "A superteatralidade, a superação mesmo do racionalismo brechtiano através de uma arte teatral síntese de todas as artes e nãoartes" (CORRÊA, 1979). Enquanto Vianninha buscava retratar os impasses, os dilemas, os conflitos de uma classe média emparedada pela ditadura, no outro polo, com seu teatro da agressão "o Oficina atacava as ideias e imagens usuais da classe média, os seus instintos e sua pessoa física. O espectador da primeira fila era agarrado e sacudido pelos atores, que insistem para que ele 'compre'" (SCHWARZ, 1992, p. 87).

Ainda que Vianninha recuse fazer um teatro no qual o público de classe média deve ser "chocado" pelas ações violentas dos atores, vê-se que, inserido no contexto da ditadura, separado da possibilidade do "teatro de ação" que fez no CPC, sua saída para os dilemas já não é posta por meio de "acontecimentos exemplares" e a "criação" que se sobrepõe à imitação do real. Ele retrata os impasses de seu tempo. A mudança de enfoque também veio acompanhada pelo movimento - presente em muitos dos ex-membros do CPC dali em diante - da autocrítica à experiência cepecista7:

(...) a gente dava prioridade ao político em detrimento do estético, criou-se uma forma estética... digamos... era o naturalismo. Que é, realmente... Não dá, ele não dá. Ele não tem condições de dar resposta aos contraditórios e profundos problemas que a realidade brasileira colocava e que em 64 passaram a ser muito mais densos e rigorosos. (VIANNA FILHO, 1974, p 162).

7 A posição apresentada por Vianninha merece uma discussão pormenorizada que não cabe nessas páginas. Vale dizer, contudo, que sua visão é contestável, uma vez que as experiências teatrais do CPC ultrapassam em muito o naturalismo, incorporando elementos épicos fundamentais, como relatamos brevemente neste artigo ao falar de "A mais-valia vai acabar, seu Edgar" e "Brasil, versão brasileira". A esse respeito Cf. COSTA, 1996. Para Vianna, a concepção do CPC privilegiava o político em detrimento do estético, e a mudança foi impulsionada pelas novas condições políticas: "[...] com os acontecimentos de 64, privilegiar o político tornou-se muito problemático. Muito difícil a atuação imediata. Para você fazer teatro em caminhões, ou mesmo peças de denúncia política. Então nós passamos a não propriamente nos preocupar com a linguagem estética, mas a nos preocupar com as condições de luta dentro do campo estético" (VIANNA FILHO, 1974, p. 163). 


\section{o voluntarismo e sua estratégia política no centro da cena}

Outro impasse retratado por Vianninha, que possui uma forte intersecção com seu retrato dos dramas e dilemas dessa classe média esmagada, é o dos caminhos políticos da oposição à ditadura. O eixo desse debate aparece em duas peças com protagonismo, ambas premiadas pelo Serviço Nacional de Teatro (SNT) e igualmente censuradas, que só seriam encenadas após a morte de Vianna: "Papa Highirte", de 1968, e "Rasga Coração", a última peça escrita por Vianna, finalizada em 1974 às vésperas de sua morte precoce.

"Papa Highirte", cujo título remete ao ditador haitiano François Duvalier, - "Papa Doc", conta uma história alegórica de um ex-ditador de uma república latino-americana que está exilado. Um dos temas centrais da peça é a relação e a discussão política entre Manito e Mariz, apresentada ao espectador em flashback, posto que Manito, no momento presente da peça, já foi assassinado pela repressão política perpetrada pelo regime de Highirte. Diego infiltra-se como funcionário do ex-ditador sob o nome de Pablo Mariz, com o objetivo de assassiná-lo e vingar a morte do amigo. 0 que vemos, nos diálogos entre Diego e Manito, é a discussão mais presente entre a esquerda no momento da escrita da peça: o embate de estratégias entre a guerrilha (também referida como "luta armada") e a estratégia do $P C B$, que seguia se pautando por uma estratégia etapista que separava a luta pela democracia da luta pelo socialismo e pela perspectiva de uma "frente ampla" de conciliação de classes unindo

(...) a classe operária e demais forças patrióticas e democráticas para a luta contra o regime ditatorial, pela sua derrota e a conquista das liberdades democráticas. (...) A burguesia nacional participa da frente antiditatorial, embora sua oposição ao regime seja limitada. (PCB, 1967).

"Papa Highirte" trata de diversas questões políticas fundamentais, com três delas como centro, como aponta Maria Silvia Betti: "o declínio do populismo caudilhista, a militância das organizações de luta armada e as transformações econômicas determinadas pela política externa dos Estados Unidos para o continente" (BETTI, 2019, p. 9). Queremos apontar aqui para o ponto de 
contato entre a crítica que Vianinha tece tanto ao teatro realizado por artistas da classe média alta quanto à estratégia política da guerrilha.

Em 1970, quando critica a montagem de Celso Nunes, Vianna discorda do diretor que afirmara ser uma divergência de "estilos", dizendo que o autor queria uma montagem "realista", enquanto a sua misturava distintos estilos. Para Vianinha, trata-se sobretudo de posicionamentos políticos diferentes. Ele diz: "A tendência da encenação para o espetáculo de invenção, para o ritual, não me abalariam, se não houvesse nessa tendência um Irrefreável apelo ao voluntarismo, que é a morte do rigor e da assiduidade na luta pela transformação da realidade" (VIANNA FILHO, 1970a, p. 132). Essa postura é associada pelo autor aos artistas da alta classe média, como uma reação de revolta frente ao aprisionamento de seu potencial criador diante de sua função social para o grande capital. Sua função de reprodutores da ordem social está em conflito com sua ânsia de liberdade criadora, e a rede de comportamentos e gestos sociais que regem essa existência castradora tornam-se o alvo de sua revolta. Assim, a destruição da lógica, da palavra, a confecção de um teatro "moral" são a forma de expressão dessa revolta, que é uma reação, conforme aponta Vianna, individual e voluntarista; algo que é permitido por uma relativa margem de manobra econômica que lhe confere alguma liberdade pessoal.

Contudo, essa saída é inaceitável para Vianinha, posto que a sua classe social e o teatro que deseja fazer, da "maioria do povo" de seu país, não pode compactuar com saídas que só estão disponíveis a "indivíduos isolados ou a categorias sociais privilegiadas". Assim, afirma que esses setores majoritários a que seu teatro almeja atender não estão interessados em mudanças de comportamento, mas sim de relações objetivas.

A crítica de Vianninha aqui parece mirar a montagem de "A longa noite de Cristal", mas na verdade está voltada contra toda uma corrente estética que surgia e se desenvolvia na época, e a inspiração estética vem de figuras como Grotowski (influência assumida de Celso Nunes nesse então). Enquanto este procurava um teatro visceral, que vem "de dentro" do ator, Vianninha buscava ancorar os dilemas pessoais nas condições objetivas da realidade. O impasse da classe média de Vianninha é histórico e social, não moral e subjetivo. 
O voluntarismo que critica nessa concepção teatral é o mesmo que aparece em sua crítica política ao guerrilheirismo em "Papa Highirte", no embate entre Mariz e Manito:

Manito: Tem de fazer, Diego, tem de fazer, a gente é feito archote!

Mariz: Não faz, Manito, não faz, não confunde teu desespero nas coisas!

Manito: Tem de fazer, Diego, feito archote, acender o rastilho!

Mariz: Ir sozinho é fácil, difícil é trazer os outros.

Manito: Começa que os outros vêm. Diz o primeiro não.

Mariz: Não confunde teu desespero nas coisas.

Manito: O primeiro não, Diego, o rastilho. (VIANNA FILHO, 1968a, p. 36)

E ainda, em outro momento, uma discussão sobre o "herói" que ressoa nos debates de Boal e Rosenfeld:

Mariz: ... Você quer ser herói eu quero fazer a revolução...

Manito: ....Você conhece alguma revolução sem herói?...

Mariz: ...Todas tiveram líder, nenhuma teve herói...

Manito: ...Jogo de palavra, você também agora jogo de palavra?... (VIANNA FILHO, 1968a, p. 42).

Ainda que aqui Mariz e Manito não sejam personagens da "alta classe média" como no teatro voluntarista criticado por Vianinha, a associação entre uma posição política vanguardista e voluntarista e esse setor social existe em outros momentos na obra do autor. Exemplo disso é Milena, personagem de "Rasga Coração", que se contrapõe a Manguari Pistolão e Camargo Moço defendendo a "ação direta" contra um plano de defesa democrático frente a punição de alguns dos alunos de seu colégio por usarem cabelo comprido:

Milena: ... é sempre isso, sempre isso, olhaí sempre isso, mas meu Deus! Primeiro aparecem os solidários, aí os aliados, aí a massa, aí os de baixo nível ideológico e aí a gente fica rondando no mesmo lugar atolados, séculos para fazer um gesto, passamos a vida discutindo entre nós mesmos.

Camargo Moço: ... nós temos que aprender a nos mover no atoleiro, é a nossa casa o atoleiro... 
Milena: ... ação direta, companheiro! Vocês acabaram com a ação direta, a fúria, a paixão... (VIANNA FILHO, 1974, p. 104).

Para Vianinha, que faz de "Rasga Coração" uma homenagem à velha guarda dos militantes, o golpe fulminante na imagem idealizada do herói - cujo modelo exemplar era Che Guevara, que havia proferido o lema passível de se transformar na bandeira do que poderia ser visto como o voluntarismo pequeno-burguês do guerrilheiro: "o dever de todo revolucionário é fazer a revolução" - era a ode ao militante do "cinzento e cotidiano", Manguari Pistolão.

Vianinha também tinha suas críticas ao "Partidão", mas não as transformava em divergência pública, segundo Ênio Silveira, porque, coerente com a visão propugnada pelo stalinismo de um tipo de "centralismo burocrático", considerava que qualquer crítica pública ao chamado "mundo socialista" acabaria por beneficiar o capitalismo (MORAES, 1990, p.182). Mas também em "Rasga Coração" o autor deixa latente a importância do espírito crítico, não dogmático, que está na voz de Camargo Moço ao responder a Manguari sobre as críticas feitas pelo filho dele, Luca:

Camargo Moço: (...) acho que, vai ver, esse foi o erro de vocês... vocês descobriram uma verdade luminosa, a luta de classes, e pronto, pensam que ela basta para explicar tudo... a tarefa nossa não é esperar que uma verdade aconteça, nossa tarefa é descobrir novas verdades, todos os dias... acho que vocês perderam a arma principal: a dúvida. Acho que é isso que o filho do senhor quer... duvidar de tudo... e isso é muito bom... acorda... arrepia as pessoas. (VIANNA FILHO, 1974, p. 122). 


\section{fora dos palcos, o "pessedismo"s}

Fora dos palcos, o debate sobre os caminhos que os artistas deveriam trilhar também coloca Vianninha como defensor das posições do PCB, mostrando que a opção por retratar a classe média como protagonista também estava relacionada à adesão ainda vigente de um projeto de conciliação de classes - e que agora tornava-se também um projeto de um tipo de "frente ampla" das artes, dissolvendo as diferenças estéticas, políticas, programáticas dos distintos setores em nome da sobrevivência do fazer teatral. Essa posição foi sintetizada em polêmica com Luiz Carlos Maciel no volume "Caderno Especial 2" da Revista Civilização Brasileira, intitulado "Teatro e Realidade Brasileira". Ali, Vianninha publica o texto "Um pouco de pessedismo não faz mal a ninguém", onde diz "(...) a luta artística assume, em primeiro plano, a luta entre duas posições no interior do teatro. Não é este o centro do problema. Na verdade, a contradição principal é a do teatro, como um todo, contra a política de cultura dos governos nos países subdesenvolvidos." (1968b, p. 124) $\mathrm{E}$, mais enfaticamente, "Na verdade, cada vez que um pano de boca se abre neste país, cada vez que um refletor se acende, soam trombetas no céu - trata-se de uma vitória da cultura, qualquer que seja o espetáculo" (1968b, p.125). Como aponta Maria Silvia Betti, apesar de que a marca do período desse debate, em 1968, seja a radicalização, tanto estética quanto política, "o 'pessedismo' de Vianinha tem seu lugar garantido na publicação e no contexto teatral, já que representa a perspectiva não apenas de Vianinha ou Dias Gomes, mas de toda a intelectualidade de esquerda ligada ao PCB, de cujo pacifismo e etapismo ele é a expressão no setor teatral" (1997, p. 228).

Coerentemente, vemos que a postura de Vianninha em defender uma diluição das diferenças em nome da luta pela sobrevivência se coaduna com os dilemas vividos pelas suas personagens de classe média, ou mesmo o antigo militante Manguari Pistolão em sua busca cotidiana por manter acesa a chama de seu ideal, enquanto se defronta com o dilema de uma nova geração que em vão procura uma revolução "por dentro" e vê a saída para o impasse histórico num recolhimento individual. A angústia muitas

8 O termo "pessedismo" faz referência ao PSD, o Partido Social Democrático, fundado por Getúlio Vargas em 1945 e que, em aliança com o Partido Trabalhista Brasileiro (PTB), e com apoio inclusive do $\mathrm{PCB}$, expressava a posição de "centro" em oposição à direitista União Democrática Nacional (UDN). Assim, Vianinha utiliza o termo para expressar uma posição conciliadora e moderada, que abrigasse todas as vertentes sob seu auspício, expressando na política cultural o que defendia o PCB no âmbito de uma política em geral. 
vezes expressa nesse impasse político de Vianninha e de suas personagens é a expressão do impasse de uma geração e uma estratégia encarnadas pelo partido ao qual o autor foi fiel até seus últimos dias. As lições, em carne viva, são a herança derradeira que o militante e o dramaturgo nos legou. 


\section{referências bibliog̣ráficas}

BARCELLOS, Jalusa. CPC: Uma História de Paixão e Consciência. Rio de Janeiro: Nova Fronteira, 1994.

BETTI, Maria Silvia. Oduvaldo Vianna Filho. São Paulo: Edusp, 1997.

. Apresentação. In: VIANNA FILHO, O. Papa Highirte. São

Paulo: Temporal, 2019.

CORRÊA, José Celso Martinez. O Rei da Vela - Manifesto Oficina. In: Arte em Revista 1 - Anos 6o. São Paulo, Kairós, 1979. Disponível em: http:// tropicalia.com.br/leituras-complementares/o-rei-da-vela-manifestooficina. Consultado em 17/06/2019.

GULLAR, Ferreira. Quando o bicho nos pegou. Folha de São Paulo, 25/09/11. In: http://feeds.folha.uol.com.br/fsp/ilustrad/fq2509201127.htm. Consultado em 17/06/2019.

COSTA, Iná Camargo. A hora do teatro épico no Brasil. Rio de Janeiro: Paz e Terra, 1996.

COSTA, Ricardo. A produção político-cultural do $P C B$ dos anos 30 aos 60 . In: https://www.marxists.org/portugues/tematica/ano/mes/cultural.htm\#tr1. Consultado em 18/06/19.

MORAES, Dênis de. Vianinha: cúmplice da paixão. Rio de Janeiro: Nórdica, 1990. - PCB. Resolução Política do V Congresso. 1960. Disponível em: https://www.marxists.org/portugues/tematica/1960/og/congresso.htm. Consultado em 20/06/19.

. Resolução Política do VI Congresso. 1967. Disponível em: https://www.marxists.org/portugues/tematica/1967/12/resolucao.htm. Consultado em 20/06/19.

ROSENFELD, Anatol. Heróis e Coringas. In: O mito e o herói no moderno teatro brasileiro. São Paulo: Perspectiva, 1982.

SALLES, Edison; MATOS, Daniel. O processo revolucionário que culmina no golpe militar de 64 e as bases para a construção de um partido revolucionário no Brasil. In: Estratégia Internacional Brasil, v. 2. São Paulo: Iskra, 2007. 
SCHWARZ, Roberto. Cultura e política, 1964-69. In: O pai de família e outros estudos. São Paulo: Paz e Terra, 1992.

VIANNA FILHO, Oduvaldo. Momento do teatro brasileiro (1958). In: VIANNA FILHO, Oduvaldo. PEIXOTO, Fernando (org.). Vianinha: teatro, televisão, política. São Paulo: Brasiliente, 1999.

A mais-valia vai acabar, seu Edgar (1960).

$\ln :$ . Peças do CPC. São Paulo: Expressão Popular, 2016.

. Do Arena ao CPC (1962). In:

PEIXOTO, Fernando (org.) Vianinha: teatro, televisão, política. São Paulo: Brasiliente, 1999.

. Brasil versão brasileira (1962). In: PEIXOTO, Fernando. O melhor teatro do CPC da UNE. São Paulo: Global, 1989.

. Um pouco de pessedismo não faz mal a ninguém

(1968a). In: ; PEIXOTO, Fernando (org.). Vianinha: teatro, televisão, política. São Paulo: Brasiliente, 1999.

Análise de uma divergência (1970a).

In: ; PEIXOTO, Fernando (org.). Vianinha: teatro, televisão, política. São Paulo: Brasiliente, 1999.

. Corpo a Corpo (1970b). ColeçãoVianninha digital.

Volume 15: Corpo a Corpo. 2007.

. Em família (1971). Coleção Vianninha digital.

Volume 14: Em família. 2007.

- Entrevista a Luis Werneck Vianna (1974). In:______ PEIXOTO, Fernando (org.). Vianinha: teatro, televisão, política. São Paulo: Brasiliente, 1999.

. Mão na Luva (1966). Coleção Vianninha digital. Volume 10: Mão na Luva. 2007. . Papa Highirte (1968b). São Paulo:Temporal, 2019. . A longa noite de Cristal (1969). São Paulo: Temporal, 2019. . Rasga Coração (1974). São Paulo: Temporal, 2018. 